\title{
Rumores do tempo
}

\section{Andrea Cristina Muraro ${ }^{1}$}

RESUMO: Este texto compara poemas de José Craverinha, moçambicano, e de Ruy Duarte de Carvalho, angolano; discutindo o entrecruzamento da memória em duas perspectivas - a do sujeito histórico e a do sujeito lírico.

ABSTRACT: This text compares poems by the Mozambican José Craveirinha, and by the Angolan Ruy Duarte de Carvalho, in order to discuss the interfaces of memory into two perspectives: from historical subject and from the lyrical subject.

PALAVRAS-CHAVE: Memória; Tempo; José Craveirinha; Ruy Duarte de Carvalho.

KEYWORDS: Memory; Time; José Craveirinha; Ruy Duarte de Carvalho.

A forma do barco onde vamos sem a ver é o mesmo Instante. Nele deslizamos, estranhamente parados, não para Eternidade, mas na Eternidade.

Atrás deixamos a espuma do Tempo.

(Eduardo Lourenço)

Ao receber a História no corpus de seus poemas, José Craveirinha (1922-2003) e Ruy Duarte de Carvalho (1941) agregam elementos externos e elaboram seus traços estruturais em matrizes e matizes de significado que convergem em uma língua em comum: a da poesia.

Mesmo que cada um deles esteja alocado em uma parte da África, respectivamente, Moçambique e Angola, não podemos deixar de observar um mapa "aberto, conectável em todas as dimensões"

\footnotetext{
${ }^{1}$ Doutoranda em Estudos Comparados de Literaturas de Língua Portuguesa; Projeto de pesquisa: Mapas poéticos de Luanda. E-mail: a.muraro@uol.com.br
} 
(DELEUZE, p.22) de suas poéticas. Uma dessas dimensões é a da memória em cujo corpo os poetas em questão apreendem, aprendem e (des)prendem o tempo por meio da interlocução; nela podemos vislumbrar a recomposição do mundo cotidiano como matéria de poesia, mesmo que saibamos de nossa impossibilidade humana em aliar tempo e espaço, o fato é que há neles a densidade do poético e do político em jogo artístico.

Em ambos, o "texto não é então a 'realidade' mas os materiais para reconstruí-la” (FERREIRA, p. 78). A memória funciona como uma vida passada a limpo em que se revê os momentos de dureza de quem testemunhou a crueldade e a insanidade do sistema colonial e da guerra civil, assim em JC temos: "palavras comedidas/segredadas conversas" e em RDC: "Gravei nas águas a fúria da conquista.", apontando para todo um "espaço de significações que os textos incorporam, e de suas relações com a memória cultural (tradição) já formada na consciência de quem ouve e vê"(FERREIRA, p. 82).

Embora estejamos falando de poesia, o que nos cabe aqui pontuar é o caráter da memória, como rumor do tempo soprando palavras em uma espécie de "móbile da memória", na expressão de Arrigucci. Já que, como nos esclarece Walter Benjamin, há dois tipos de narrador: o que viajou muito e tem o que contar para sua comunidade e o que aprendeu com seu país, conhece suas histórias e tradições; nesta senda, podemos localizar tanto JC quanto RDC.

Entretanto a contar dos dados biográficos, preferimos o segundo tipo já que além de poetas cada qual no seu formato de articulação, também, retiveram Moçambique e Angola em suas histórias pessoais de militância - enquanto JC nos dá a Moçambique de sua ancestralidade (mãe ronga e pai português) ou como habitante de Mafalala ou como jornalista (cronista do tempo presente); RDC impressiona pela originalidade de abordagem: percorre seu país como regente agrícola, cineasta e antropólogo - sempre em direção a seu interior, concebendo Angola de dentro, o que já é de saída uma postura diferenciada pois a 
maior parte da produção angolana centra-se em Luanda, a cidade capital na representação literária.

Impossível ignorar, portanto, ambas as experiências cotidianas transformadas em lavra poética: preparam a terra, revolvem imagens e as registram em suas escrituras. De posse de tal memória, percorrem caminhos de singularidades pessoais e pluralidades fátrias dentro do sistema de literaturas de língua portuguesa, num "mundo vasto mundo" como diria Drummond.

A respeito de apontar singularidades, adentremos o poema Prémio de JC, constante em Maria (1988), obra que em seu conjunto “deixa ver a prisão, a militância, a vida familiar"(CHAVES,p.XXX); mais do que isso, é permeada principalmente pela presença de sua interlocutora: a esposa morta cuja ausência marca, em solidão, a lírica como lugar de reencontro: "como custa reter-te atormentada neste poema"(CRAVEIRINHA, p.136). Nas duas estrofes, anteriores a este verso em conclusão, o poeta nos mostra um processo metonímico em “constantes alertas/ gestos acautelados” em que fica bastante evidente a interpenetração de modelos europeus e africanos. Em resposta a primeira estrofe, toda ela nominal (como tema no sentido europeu da poesia) - temos com exceção do último verso - a segunda estrofe em perguntas retóricas (como desenvolvimento do tema), típicas do legado oral africano em recomposição cíclica. Esta estrutura dialógica é iniciada, em todos os versos, pelo tecido da conjunção 'e' que coordena e não subordina - um certo lastro da língua ronga, na continuidade lírica em parataxe.Nesta combinação, a língua portuguesa do colonizador é rompida.Lírico e histórico fundem-se ao dar voz à função social e ideológica da palavra marcadamente pautada na coreografia da estrofe: "E papéis escondidos/rusgas?", "E terceiros ouvidos/telefonemas?E olhares de esguelha/esquina?".

Como a observar cenas filtradas da memória latente, desvela: " $\mathrm{E}$ marmitas revistadas/dias de visita?", para nos deixar entrever a resistência em recuperar e manter Maria no cotidiano da visita à prisão, eclodindo na imagem popular do zé e da maria, perene e 
simples, já que aqui a matéria cotidiana e histórica torna-se consciência utópica, do devir do título: um prêmio. Na recuperação do instante/tempo, entre gestos e palavras silenciadas, encerra-se a exclamação de um espaço de reencontro: “neste poema!”.

Nestas "armadilhas da memória", já que é "sempre incompleto um discurso sobre a memória, do mesmo jeito que a memória abarca e despreza fatos e coisas e a outras faz renascer vivificadas e perenes" (FERREIRA, p. 67), JC nos permite adentrar o homem que se desespera na segregação e no confinamento, mas a matéria utópica com que é lavrada sua poesia o recompõe, se um dia lhe "levaram os livros e as malas como reféns políticos”, como escreve em outro poema, a memória aqui está reivificada na evocação à Maria, na companheira, que nem mesmo o regime colonial esfacelado em ouvidos e olhares pôde apagar.

Em literatura comparada é necessário pensar, também, sobre como as articulações se processam; em virtude disso, ao nos depararmos com o título da coletânea Memória de tanta guerra (1992) de RDC mais uma vez nos valemos de W. Benjamin, quando nos explica que " a poesia épica traz em seu corpo a tradição oral” (p.195) e em RDC esta tradição se corporifica quando o narrativo toca o lírico, assim como em JC, a contar da estrutura composta de versos livres e alongados tendendo à prosa: sinais da modernidade lírica dos poetas em seus aspectos externos abarcando - na forma - o 'eu’ que se posta como aquele que tem o que contar. Portanto em ambos não há a "morte do narrador", há sim a presença do 'eu' que se atravessa na memória presentificada de experiências e desvela seu conteúdo nas forças formais da língua, tanto do exterior (geografia) quanto do interior (memória) de seus textos que se realizam de maneiras diferentes, mas plenos de determinados aspectos de suas experiências históricas.

Um dos poemas que compõe a antologia de RDC é A gravação do rosto, composto de 12 estrofes em que a força transformadora reside na transumância com que o sujeito percorre obra/ espaço sem deixar de, metonimicamente, orquestrar "rosto /mão /vontade/ esperma” pelo terreno cultivado que é a palavra. Neste ponto de intersecção - no como 
a memória retém - é que as obras de JC e RDC entrecruzam-se, pois ambos deslocam a memória com o tempo do continuum.Neste movimento da poeticidade, o "discurso poético apreende muito mais aí do que se poderia fazer de outro modo, e nos oferece sobre a noção de identidade cultural páginas extraordinárias, que trazem do pessoal ao social, em sucessivas ondas" (FERREIRA, p. 48).Dessa maneira, os textos se retroalimentam tanto em memória como em esquecimento, porque é preciso lembrar para esquecer.

Tomado na dialética dos gestos, o poema de RDC percorre a tematização lingüística da terra, pontuando o silêncio, entre as estrofes como marca de contenção, com o qual intercala cenas de grandiosidade dos elementos da natureza (savanas/ desertos/ grutas/ montes/ outeiros ) sem deixar de aproximar o texto da vida, sem exotismos, apenas andanças de quem gesta paisagens.

Através do movimento de imagens refratadas: "naveguei no ventre deserto /ergui torres girassóis gigantes”, o poeta grava os ritmos da oralidade africana com suas marcas: " assinalei o umbigo do mundo". Acedendo "fogueiras" como os griôs, RDC revela um espaço do texto/tempo em que o 'eu' difrata-se na matéria pluralizada da geografia: "sonhei europas/ antárdidas caiadas", sem deixar de ser o homem - e aqui retomamos novamente W. Benjamin - que viajou muito e tem o que contar.

Em um exercício de deslocamento de espaços, sua "gravação" segue em versos, pulsando em um mapa de sons ora vibrantes ora oclusivos que moem e remoem a obra em construção na "superfície branca do deserto" em forma de papel. Na "atmosfera ocre das distâncias" sinalizam-se valores utópicos do "verde breve da chuva de Novembro" em sutil referência ao dado histórico angolano - como um Ulisses e sua cicatriz - marca a data da independência angolana: novembro de 1975. Neste tom épico, reside o presente pleno sobreposto de imagens pátrias e ao mesmo tempo ancestrais, pois se revestem de um "rosto" como identidade, máscara destas várias identidades; para 
isso, o poeta as agrega em um corpo telúrico, com "a mão" que pesa "calcários" e "granitos", colhe e semeia "milhos" e "calhaus".

Através da rocha infértil partilha com seu interlocutor "a devolução do amor" da primeira estrofe, em um discreto "tu sabes": "bordei-te flores no canteiro do céu" ou cobre-se de "zinco" nas "solidões" e "esperanças"; quando a terra não revela o "verde" da narrativa em versos, o lírico busca no céu do "aqui" tão reiterado em anáforas pelas estrofes; em um olhar utópico empilha versos para cima: "madrugadas de atenção" a contar "estrelas" e colher "algumas”.

Tais delicadezas, entreabrem-se num movimento perpetuado pela transitividade dos verbos em pretérito perfeito (prendi/ gravei/ cumpri/ pari/ dei/ vi/ espremi/ disparei/ combati/ saltei/ naveguei/ beijei/ semeei/ colhi/ assinalei...), preenchidos com o gesto de fertilizar: “ejaculei delírios verdes", atualizando o texto de "vontades" (fiz/ desfiz, refiz amores) executadas em ciclo infinitivo ( nascer/ morrer); assim, o poeta experimenta o tempo presente da última estrofe (abalo/ apalpo/ afago/ ordeno) como a indicar que o "aqui" mapeia sua semântica de ar, terra, água, fogo; dando forma a um sujeito "parido para o nada", impulsionado pelo tempo no devir do "vou" para "daqui" explorar outras longitudes e latitudes do ser, do "homem que habita poeticamente o mundo" (HÖLDERLIN).

Ao cotejarmos JC e RDC, situamos a memória como forma de apreensão temporal e suas correlações em dois planos - o do sujeito histórico e o do sujeito lírico. Nesse desvão tão caro à poesia, os poetas se completam em métodos de sintaxe: o primeiro, nomeia a memória e o segundo, a verbaliza.

Tal interface se dá por meio de uma estética que busca desmedidas geográficas pautadas pela solidão dos atos da memória: "esperei por ti" e "como custa reter-te..." e justificadas pelo caráter utópico das literaturas de língua portuguesa : "Prémio" e " Daqui abalo hoje”.

Na partilha dos versos, ambos recuperam em sua práxis o passado como forma de alimento, sustentáculo para fazer-se humanizar 
por meio do poético. Com isso, rompem as estruturas (incorporando o ritmo à sintaxe) e projetam-se em travessias na qual homem e história, bem como poeta e História condensam-se, já que " o paradoxo do Instante é o nunca ter principiado e não poder ter fim" (LOURENÇO,p. 39).

\section{Referências bibliográficas:}

ARRIGUCCI JR., Davi. Enigma e comentário. São Paulo: Cia. das Letras, 1987. ABDALA JR., Benjamin. Literatura, história e política. São Paulo: Ática, 1989. BENJAMIN, Walter. O narrador. In: Magia e técnica, arte e política.10.ed. São Paulo:

Brasiliense, 1996, p. 197- 221.

CARVALHO, Ruy Duarte. Memória de tanta guerra. Antologia poética. Lisboa: Veja, 1992.

CHAVES, Rita. Angola e Moçambique. São Paulo: Ateliê, 2005.

CRAVEIRINHA, José. Maria. Lisboa: Caminho, 1998, p. 136.

DELEUZE, Gilles \& Guattari, Felix. Introdução: rizoma. In: Mil Platôs. Trad. Aurélio

Guerra. Vol. 1. Rio de Janeiro: Ed. 34, 1995, p. 11- 39.

FERREIRA, Jerusa Pires. Armadilhas da memória. São Paulo: Ateliê, 2003.

LOURENÇO, Eduardo. Tempo e poesia. Porto: Editorial Inova, 1974. 